
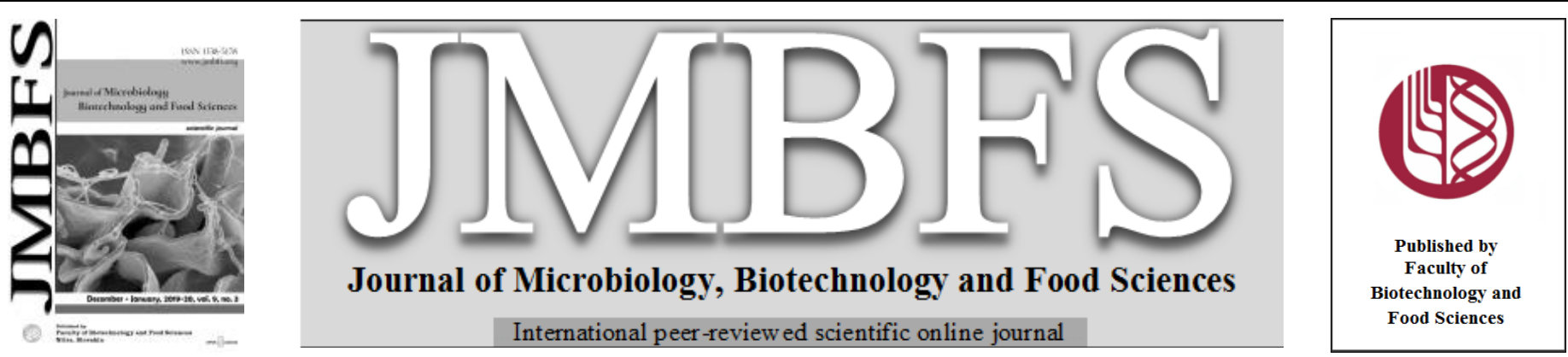

\title{
A SMARTPHONE-BASED EARLY ALERT SYSTEM FOR SCREENING OF COLIFORM CONTAMINATION IN DRINKING WATER
}

\author{
Rajshree Patil*I, Saurabh Levin ${ }^{1}$, Nischal Halery ${ }^{I}$, Ishan Gupta ${ }^{I}$ and Samuel Rajkumar ${ }^{l}$
}

Address(es): Rajshree Patil,

${ }^{1}$ Foundation for Environmental Monitoring (FFEM), \#70 (old \#125), $2^{\text {nd }}$ floor, Infantry Road, Shivaji Nagar, Bangalore, 560001, Karnataka, India.

*Corresponding author: rajshree@ffem.io

doi: 10.15414/jmbfs.2019/20.9.3.539-547

\section{ARTICLE INFO}

Received 6. 6. 2018

Revised 4. 6. 2019

Accepted 4. 6. 2019

Published 1. 12. 2019

Regular article open $\odot$ access

\begin{abstract}
We present a proof of concept for quick screening and alerting of coliform/E. coli contamination in water samples using a device attached to a smartphone. Current methods of coliform detection rely upon relatively expensive laboratory-based time consuming techniques which require trained manpower and take at least $24-48$ hours. This waiting time prevents quick action and the consequences can be severe since the contaminated water may already have been consumed by then. Instead an unattended smartphone can continuously monitor the sample and send an alert as soon as contamination is detected. Smartphones, especially older or unused ones, fitted with a customized compact incubator and a sample holder, can be set to take photos of the sample (mixed with a selective growth medium) at regular intervals. An image analysis algorithm would analyze the photos and predict contamination as soon as it notices any increase in turbidity and/or change in color of the sample under observation due to bacterial growth. On detection of contamination, alerts can be immediately sent out to the concerned parties and intervention can be made without any potentially harmful delay. To test this concept we built a prototype for the detection of coliform $/ E$. coli contamination in water samples. With the initial bacterial counts varying from 1-10 to $>10^{8}$ colony forming units (CFU) per $100 \mathrm{ml}$ of water samples, all the results were produced within a turnaround time of 4 to 12 hours and found to be comparable with conventional microbiological methods which require 24-48 hours of incubation.
\end{abstract}

Keywords: Smartphone; E. coli; Coliform; Contamination; Image analysis; Turbidity

\section{INTRODUCTION}

Contamination of drinking water by pathogenic microorganisms is one of the crucial issues with regard to human health (Ashbolt, 2015). Coliform bacteria like Escherichia coli (E. coli) is universally present in large numbers in the feces of warm-blooded animals and thus their presence in water bodies and food has been adopted as an indicator of fecal contamination (Martin et al., 2016; Odonkor and Ampofo, 2013). Coliform contamination in drinking water is primarily tested by widely accepted traditional methods such as most probable number (MPN) and the membrane filtration (MF) technique (APHA, 2012) These methods mainly use specific growth medium and incubation conditions that favor the growth of these bacteria while suppressing the growth of others. The growth is usually observed as turbidity in liquid media or colonies on solid media. The major limitation of these methods is that they are time consuming and takes a minimum of $24-48$ hours to provide results. Without timely intervention the community could be exposed to severe health risks (Heijnen and Medema, 2009; Holme, 2003; Nygård et al., 2006; Mendes Silva and Domingues, 2015) For example, a Salmonella outbreak in Alamosa city, Colorado led to 442 reported cases of illness and one death. The severity of the outbreak could have been prevented if the authorities had known about the contamination at an early stage (Haas et al., 2011; Falco and Williams, 2009).

Different molecular and immunological methods of bacteria detection such as enzyme-linked immunosorbent assay (ELISA) (Esfandiari et al., 2017; Ezenarro et al., 2018), polymerase chain reaction (PCR) (Atlas and Bej, 1990; Horakova et al., 1991; Kong et al., 2002; McMahon et al., 2018; Fatemeh et al., 2014; Walker et al., 2017), reverse transcriptase polymerase chain reaction (RT-PCR) (Bellin et al., 2001; Takahashi et al., 2017) and fluorescent in situ hybridization (FISH) (Del'Duca et al. 2015; Oliveira et al., 2016; Price and Wildeboer, 2017; Zulkifli et al., 2017) although specific and viable alternatives to the conventional culture-based methods for delivering quantitative result in a fairly short period of time (6 to 8 hours), still require expensive laboratory equipment and skilled technicians (Girones et al., 2010; Rompré et al., 2002). Moreover, as a preventive measure, frequent monitoring of water for bacterial contamination is required to be carried out at places where there is a possibility that the population will suffer from waterborne diseases. In such cases, setting up a testing facility equipped with the necessary equipment and technicians is often not possible for short term projects. Also, due to poor infrastructure facility, in most remote areas in developing countries, transportation of samples to the water testing laboratories is difficult, especially within the recommended time frame (usually 6 hours) (APHA, 2012). Such delays in testing can potentially lead to false negative results due to the alteration in the sample characteristics (McDaniels and Bordner, 1983). The outbreaks of waterborne diseases at different locations like Cabool in 1989, Milwaukee in 1993, Gideon in 1993 and Washington in 1999 are well-known examples associated with false negative errors in monitoring water bodies (Hasan et al., 2009; Hrudey et al., 2006). Mobile laboratories, a possible means to solve this issue, are expensive to set up and maintain, while a temporary laboratory is justified only if a large sampling and analysis is scheduled to be carried out within a relatively small area. Field water test kits may be suitable alternatives to the classical techniques (Bain $\boldsymbol{e t}$ al., 2012; CDC, 2010), but they too take up to 24 to 48 hours to provide the results because the detection is usually based on manual interpretation. Other issues with these include, poor consolidation of the data by the field workers due to the lack of specific skills in interpreting the tests and sometimes error due to incorrect labeling or missing of labels on sample vials, errors while recording data on paper or during data entry on computer is also possible (Rangeti et al., 2015; Rizak and Hrudey, 2006; Rizak and Hrudey, 2007).

Considering the limitations of available coliform detection methods for a mass screening of possible microbiological contamination in an acceptable time frame, a fast and low-cost detection method suitable for screening microbial contamination in the field is highly desirable. Recently, use of smartphone has been gaining popularity in the field of rapid detection methods for analyzing contamination in water. The different features of smartphone such as digital camera, sufficiently fast processor, visual display and wireless data transfer capabilities makes them ideal detection system for measuring and simultaneously transferring data to cloud databases. Recently, several research articles have been published demonstrating feasibility of the smartphone for detecting chemical and microbiological contaminants in water, food and clinical samples. For example, an enzyme-substrate based colorimetric detection platform for analyzing water contaminants using smartphone (Gunda et al., 2014; Gunda et al., 2016); a smartphone based fluoride detection device (Levin et al., 2016); evaluation of 
Mie scatters using gyro sensor and digital camera of a smartphone for analyzing bacterial contaminants in food sample (Liang et al., 2014); smartphone for detecting $\mathrm{pH}$ and nitrite in water sample (Lopez-Ruiz et al., 2014); use of smartphone camera to evaluate Mie scatter of immunoagglutination reaction (Park and Yoon, 2015); a paper based sensor for monitoring pesticide using smartphone (Sicard et al., 2015); and development of a smartphone app for quantifying $\mathrm{pH}$, protein, and glucose (Yetisen et al., 2014). A comprehensive review on smartphone application as a detection tool was done by Rateni $\boldsymbol{e t}$ al (2017). However, most of the work described in the art required manual intervention either in terms of capturing images or for transferring data to the user. Moreover, the methods used for detecting microbial contaminants based on cultivation approach do not explain systems required for on-site cultivation of bacterial cells. Considering these aspects a smartphone based platform has been explored in the present work for detection of microbial contaminants in water. The paper describes a proof of concept for a low-cost preliminary screening too to detect and provide an early warning for coliform contamination in drinking water using a smartphone with a custom designed attachment. The system augments the proven principle of measuring the growth of bacteria by automating the detection, thereby, dispensing with a delayed and error prone manual interpretation. The concept is to incubate the water sample along with a coliform specific growth media and monitor the gradual increase in turbidity due to multiplication of bacteria. A smartphone app was developed to capture and analyze images of the sample to detect any increase in turbidity over time. It is expected that as a consequence of bacterial growth, images of the sample taken at regular intervals should show an increase in blurriness over time. Once the system detects a sign of bacterial growth, an alert is immediately communicated to any interested parties via a messaging system. The turnaround time for sending the alert could be around 4 to 12 hours depending on initial concentration of bacterial cells. Other information such as geo-location, water source, pictures, etc. can also be captured on-site, and communicated as an early warning signal on any possible outbreaks of waterborne diseases.

\section{MATERIAL AND METHODS}

\section{Design concept}

The schematic diagram of the hardware setup designed to detect coliform using a smartphone is illustrated in figure 1 .

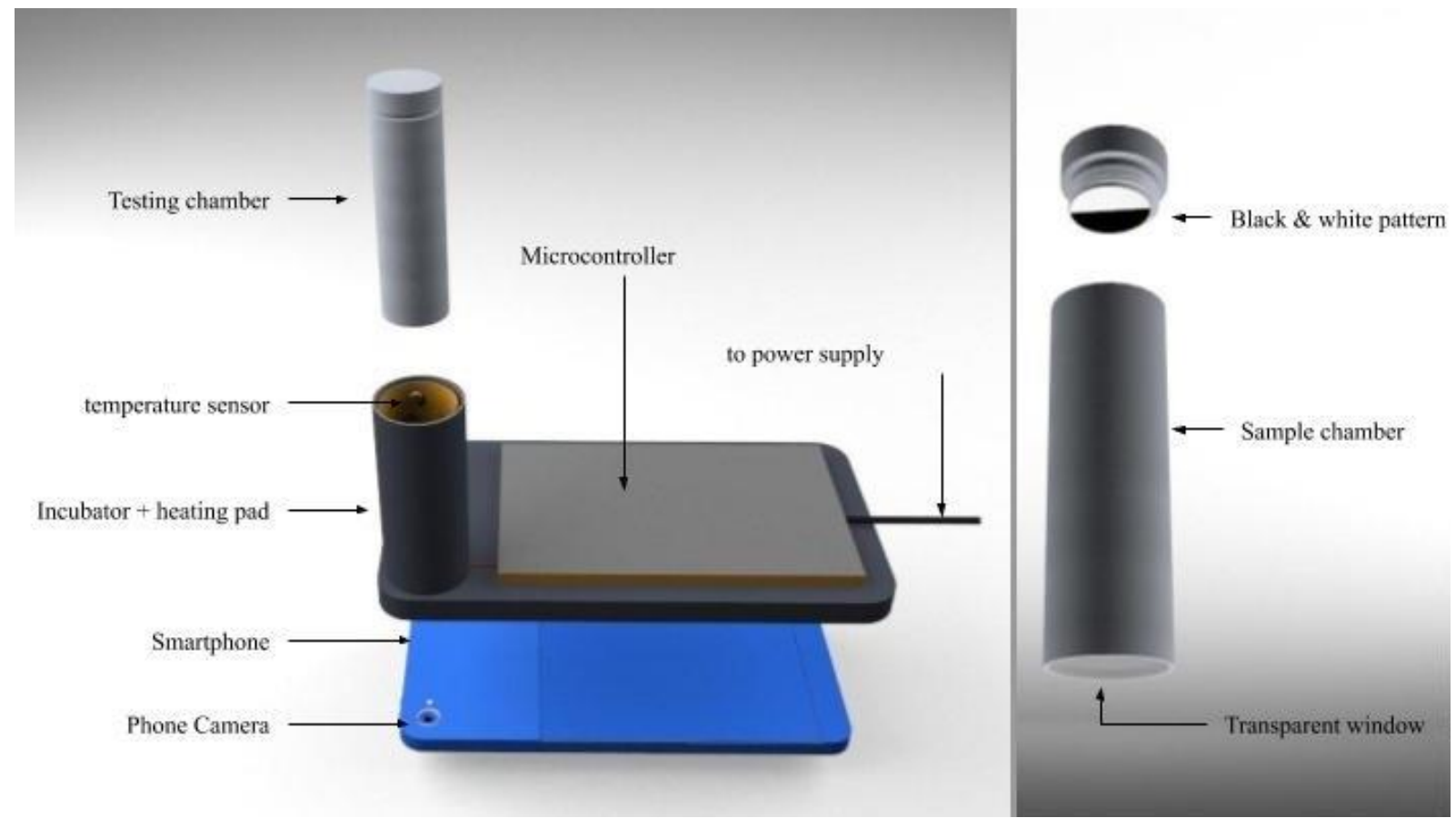

Figure 1 Schematic diagram of the coliform detection system using a smartphone, The key components of the hardware setup include

\section{Test Chamber}

The test chamber can be made up of sterile glass or plastic, and is designed to hold the water sample with coliform specific growth media. Although we sterilized the test chamber by autoclaving it at $121^{\circ} \mathrm{C}$ for 15 minutes to enable reuse, in the field the test chamber would be provided as disposable one time use consumables with sterile growth medium in the powdered form (to avoid contamination while transferring growth media in the test chamber). During the test, the outer surface of test chamber was decontaminated by wiping with $70 \%$ isopropyl alcohol. After that sample and growth medium were poured into the test chamber via the opening on the top, which is then closed with a lid. The bottom of the test chamber is made of clear transparent plastic material, allowing the camera to take photos of the content. The height of the test chamber is about $5 \mathrm{~cm}$ providing an optimum focal length for the camera to perceive a black and white pattern that is placed beneath the inner side of the lid.

\section{Incubator}

The cylindrical incubator, made from plastic, holds the heating coil around the test chamber. It consists of a heating element (Resistive heating pad by SparkFun Electronics ${ }^{\circledR}$ ) and a microcontroller-based thermostat to maintain the temperature at $37{ }^{\circ} \mathrm{C}$ or $44{ }^{\circ} \mathrm{C}$ required for optimum multiplication of target bacteria. The incubator requires a power supply of $9 \mathrm{~V} / 1 \mathrm{Amp}$. Although we used an AC/DC adapter to power the incubator, a motorcycle or car battery can be used in the field. The incubator can be set to $37{ }^{\circ} \mathrm{C}$ to detect total coliform or 44
${ }^{\circ} \mathrm{C}$ to detect thermotolerant coliform. The temperature would oscillate at about \pm 2 ${ }^{\circ} \mathrm{C}$ from the set temperature due to the heating pad being turned on and off by the microcontroller based on the readings of a temperature sensor placed on the test chamber.

\section{Back case}

A plastic rig glued to the outer surface of a removable smartphone back case (commonly available in the market) allows for the device to be attached to the smartphone. By this, the smartphone itself needs no modification. The back case was attached to the phone and the device was then fastened to the rig. This arrangement also ensures that the test chamber correctly aligns with the phone camera. On completion of the test the device can be removed by detaching the back case from the smartphone.

\section{Smartphone Model}

The data presented in this work were collected using Asus Zenfone $\mathrm{C}$ model smartphone (Android version 4.4.2). The built-in camera in this model has a pixel density of 5 Megapixel (MP) with autofocus feature, which is modest as compared to the market standard (approximately $10 \mathrm{MP}$ ). The test should be reproducible with other smartphone models. Figure 2 is a photograph of the coliform detection device (laboratory prototype) and its components fabricated based on the concept as shown in figure 1 . 
a)

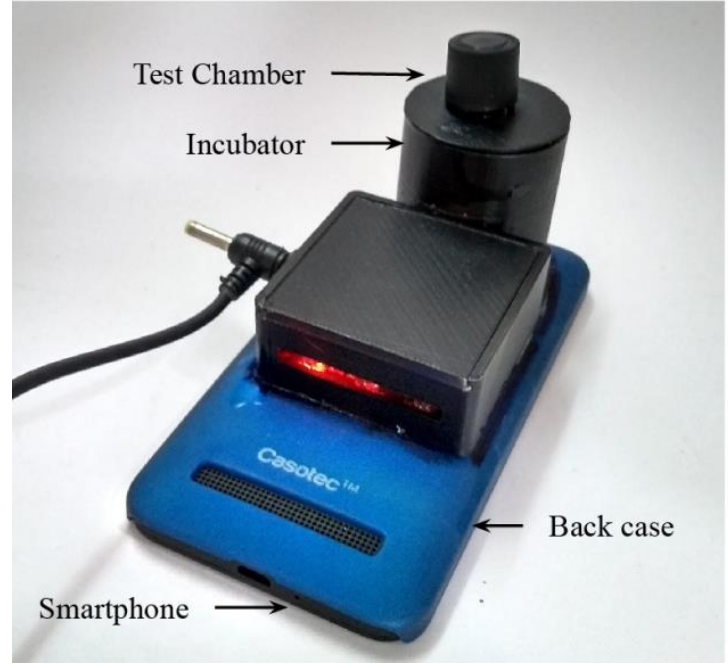

b)

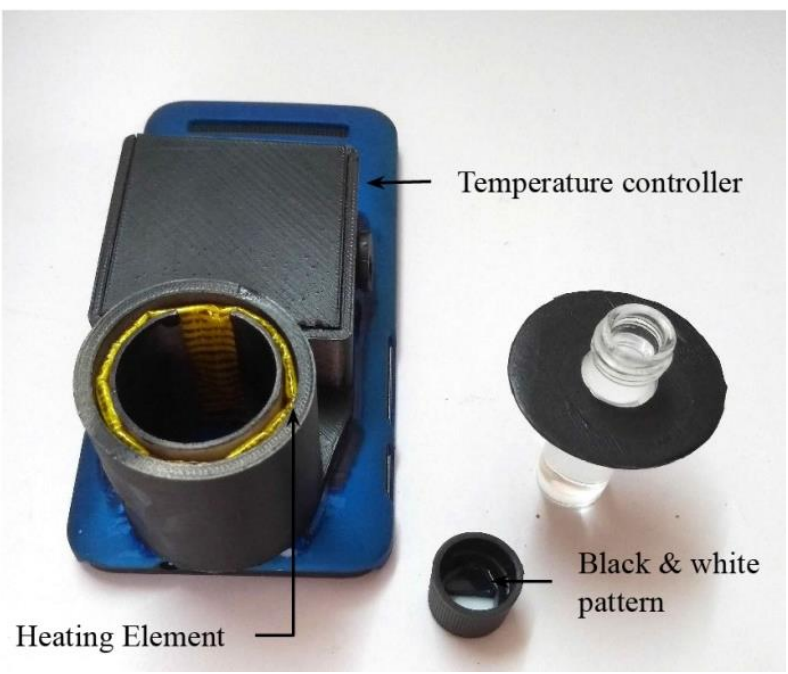

Figure 2 Coliform detection device (Laboratory prototype) a) working prototype, b) individual components

\section{Experimental}

\section{Test culture}

The present study was conducted using Escherichia coli (E. coli) NCIM 2277 as a model coliform bacteria for validating the test concept. The stock cell suspension of $E$. coli was prepared by growing the cells on A1 agar (HiMedia ${ }^{\circledR}$ Laboratories, India) at $37{ }^{\circ} \mathrm{C}$ for 24 hours. The grown cells were washed off using sterile normal saline. The sterile saline was prepared by adding $0.85 \mathrm{~g}$ (w/v) sodium chloride in $100 \mathrm{ml}$ of distilled water followed by autoclaving at 121 ${ }^{\circ} \mathrm{C}$ for 20 minutes. The washed cells were pelleted out by centrifugation at 4500 RPM for 20 minutes. The cell pellet was washed twice using sterile normal saline followed by centrifugation for 10 minutes. Finally, the washed cell pellet was suspended in $100 \mathrm{ml}$ normal saline and use as a stock cell suspension. The cell density of this stock cell suspension was adjusted to obtain a final cell concentration in the range of $10^{8}-10^{9} \mathrm{CFU} / \mathrm{ml}$ using McFarland turbidity standard. The actual concentration of stock cell suspension was determined using pour plate method. This stock cell suspension was used for preparing artificially contaminated test water with different concentrations of $E$. coli.

During the study two bacterial strains viz., Bacillus subtilis (NCIM 2920) and Pseudomonas aeruginosa (NCIM 2036) were used as negative control, whereas Citrobacter freundii (NCIM 5315) was used as a positive control strains in addition to E. coli NCIM 2277. These positive and negative control strains were mainly used to conform to specificity of selective growth media used during analysis of water samples collected from different locations. The positive strains used were group of coliform bacteria which supposed to show growth and color formation in the media. Whereas, the negative strains used were of Bacillus sp. (Gram positive, non coliform) and Pseudomonas sp. (Gram negative, non coliform) should not show any growth or color formation in the media. While testing, we have manually spiked the positive and negative strains in sterile tap water, and the tests were run in parallel as a reference of positive and negative control. These control bacterial strains were cultured in nutrient broth medium (HiMedia) overnight at $37^{\circ} \mathrm{C}$. The stock cell suspensions of these bacteria were prepared by following similar procedure as described for E. coli. All the strains used in the study were obtained from National Collection of Industrial Microorganisms (NCIM), Pune, India.

\section{Test water}

During the study, water samples contaminated with different concentrations of $E$. coli ranging from $10^{0}-10^{1}, 10^{2}, 10^{3}, 10^{4}, 10^{5}, 10^{6}, 10^{7}, 10^{8}$, and $10^{9} \mathrm{CFU} / 100 \mathrm{ml}$ were prepared by further diluting the stock $E$. coli suspension using sterile normal saline. At each testing point a specific amount of bacterial cell suspension was spiked in 2 liter of sterile tap water as per the required cell concentration and used to test the performance of the prototype with respect to detection time. The actual concentration of bacterial cell in the test water was determined using pour plate method after diluting the sample appropriately in case the bacterial cell was assumed to be in the range above $10^{3} \mathrm{CFU} / 100 \mathrm{ml}$. Whereas, for determining bacterial concentration in the range of 1 to $10 \mathrm{CFU} / 100 \mathrm{ml}$ membrane filtration assay was used (APHA, 2012).

\section{Growth media}

A ready-to-use, rapid HiColiform ${ }^{\mathrm{TM}}$ broth, recommended for specific growth of coliform/E. coli from HiMedia ${ }^{\circledR}$ Laboratories, India [Composition: peptone, $5 \mathrm{~g}$; sodium chloride, $5 \mathrm{~g}$; sorbitol, $1 \mathrm{~g}$; dipotassium hydrogen phosphate, $2.7 \mathrm{~g}$; potassium dihydrogen phosphate, $2 \mathrm{~g}$; sodium lauryl sulphate, $0.1 \mathrm{~g}$ chromogenic substrate X-Gal (5-bromo-4-chloro-3-indolyl- $\beta$-D-galactoside), $0.08 \mathrm{~g}$; fluorogenic substrate MUG (4-methylumbelliferyl-beta-D-glucuronide), $0.05 \mathrm{~g}$; IPTG (Isopropyl $\beta$-D-1-thiogalactopyranoside), $0.1 \mathrm{~g}$ per liter of distilled water and having a final $\mathrm{pH}$ of $6.8 \pm 0.2$ ] was used throughout the study. The media were sterilized by autoclaving at $121^{\circ} \mathrm{C}$ at $15 \mathrm{lbs}$ pressure for 15 minutes. The presence of total coliform after incubation is indicated by the bacterial growth and development of blue-green colorations in the medium due to the cleavage of the chromogenic substrate by $\beta$-D-galactosidase enzyme found in coliform.

\section{Test Procedure}

The experimental procedure used for validating the concept using the laboratory prototype involves filtering $100 \mathrm{ml}$ of artificially contaminated water sample through sterile $0.45 \mu$ membrane filter paper (Millipore, India) using a membrane filtration unit. After filtration the bacterial cells trapped on the membrane filter were suspended in a sterile vial with $5 \mathrm{ml}$ of coliform specific growth media by moderate shaking. The growth media suspended with bacterial cell was then transferred into the sterile test chamber (Note: the industrial design of the test chamber will be integrated with filtration unit and provided with sterile growth media in powdered form to avoid contamination while eluting bacterial cell in growth media and transferring the same in test chamber. Description of such design is beyond the scope of this study). The test chamber was then fixed above the mobile phone camera using a plastic rig attached to the back case as shown in figure 2. During the study, a total of 200 samples spiked with different E. coli concentrations were tested to the concept. The actual concentration of $E$. coli present in the water was determined using the pour plate and membrane filtration technique (mainly to capture low concentration of bacteria) as per the procedure described in APHA (APHA, 2012). In addition, at each test point, two additional control tests were run, one solely with growth media to test it's sterility and the second with sterile unspiked test water to determine any variation in growth media after adding test water. All experiments were conducted in triplicate using independent test chamber and smartphone. The incubation time derived was based on an average obtained with at least three tests.

\section{Testing water samples collected from different locations}

In addition to the artificially contaminated water sample, the system was also tested with 35 different drinking water samples collected randomly from different location of Bangalore city, India. The samples were mainly collected from the small roadside restaurants, tea stall, households located at Kalyan Nagar, Rabindranath Tagore Nagar (RT Nagar), Uttarahalli and Nandini layout. For each test, sterile polystyrene bottles (capacity $250 \mathrm{ml}$ ) were used to collect at least three replicates for each sample. Before analyzing, each sample was tested for the presence of residual chlorine using Test-Chlor reagent (Merck, India) as per the procedure described on the reagent bottle. If positive for chlorine, the samples were neutralized using neutralizing agent $(0.1 \% \mathrm{w} / \mathrm{v}$ sodium thiosulphate in distilled water) before commencing for actual test as per the UNEP/WHO (1996) guidelines for collecting water samples for microbiological analysis. The presence/absence of coliforms in these water samples were also evaluated using the standard membrane filtration technique (APHA, 2012). In parallel, the device was also tested with positive and negative control test water as a reference. The controls were prepared by adding the stock cell suspension of the respective bacterial strains in a sterile tap water to generate concentration of these bacteria in the range of $10^{2} \mathrm{CFU} / 100 \mathrm{ml}$. The control samples used during analysis 
includes, i) sterile tap water spiked with positive and negative control bacterial strains and ii) sterile tap water, iii) media control.

\section{RESULTS AND DISCUSSION}

Coliform detection via smartphone app

The smartphone app developed for this purpose monitors the sample for a certain length of time, typically about 12 hours. During this period, the images of the water sample with the growth media in the incubated test chamber were taken at an interval of 10 minutes via the smartphone camera. These images are analyzed over time by the app to check for the presence of bacterial activity by measuring the increase in turbidity. The change in color of the growth media due to enzymatic breakdown of chromogenic substrate was also captured in the photos. Figure 3 shows images of progression of growth of $E$. coli with an initial concentration of $1.5 \times 10^{3} \mathrm{CFU} / 100 \mathrm{ml}$ captured by smartphone camera through bottom transparent window of test chamber.

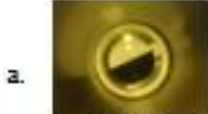

00:00

b.

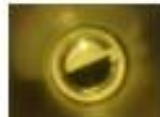

01:30

c.

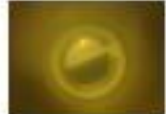

03:00

d.

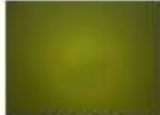

04:30

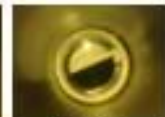

00:10

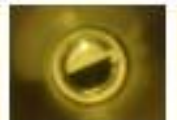

01:40

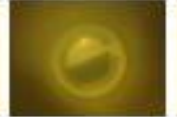

03:10

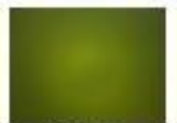

04:40

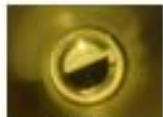

00:20

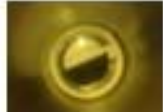

01:50

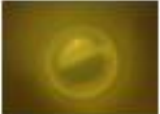

03:20

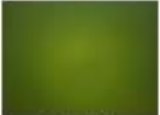

04:50

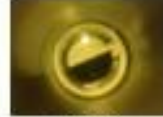

00:30

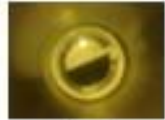

02:00

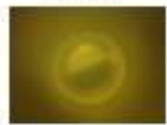

$03: 30$

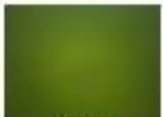

05:00

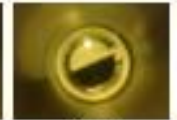

00:40

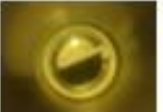

02:10

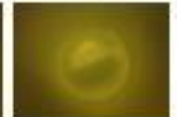

$03: 40$

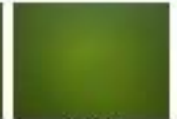

05:10

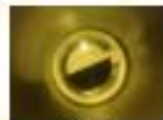

00:50

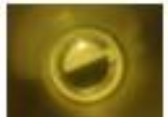

02:20

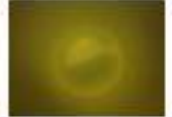

03:50

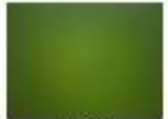

05:20

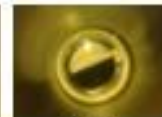

01:00

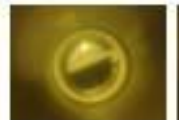

$02: 30$

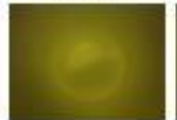

04:00

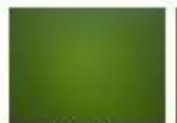

05:30

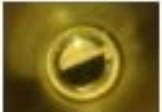

01:10

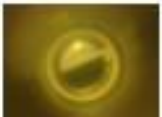

$02: 40$

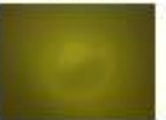

04:10

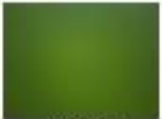

05:40

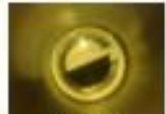

01:20

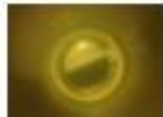

$02: 50$

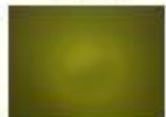

04:20

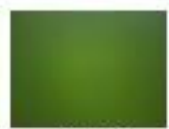

05:50

Figure 3 Progression of $E$. coli growth in coliform specific growth media captured by smartphone camera through the bottom transparent window of the test chamber (the time in hours is indicated beneath each image) a) the backdrop pattern is clearly visible, b) the pattern starts to become unclear, $c$ ) the pattern is completely obscured, $d$ ) color change in growth media becomes distinct (yellow to bluish green)

As seen in figure 3, the backdrop pattern was clearly visible up to 1:20 hours (a). After that images started to become unclear up to 4:20 hour (b and c) and all the following images were completely obscured (d). The color change in growth media (yellow to bluish green) starts becoming distinct after 4:30 hours. The app will consider the point where the image starts becoming unclear from the origina image (as can be seen after 2:50 hours) as detection time for determining coliform contamination. This information was saved on the app, and uploaded to the cloud when possible for dissemination either by short message service (SMS), Bluetooth or Wireless Fidelity (Wi-Fi) network. In addition, the app will also provide a simple traffic light form indication for bacterial contamination at the sample source. This would be especially useful for communities and the general public. Without using image processing app and automated alert system the same test would need the expected time of 18-24 hours.

\section{Image analysis by smartphone app}

Table 1 illustrates the sample of images taken during a test with an initial E. coli concentration of $10^{3} \mathrm{CFU} / 100 \mathrm{ml}$ using coliform specific growth medium and the threshold values. After gray scaling the images, the first image being the clearest is used to select the areas to analyze. Firstly, the app uses the HoughCircles function from the Open Source Computer Vision Library (OpenCV) library to find the large circle in the image which constitutes the underside of the test chamber lid. Next the app recognizes the dark and light halves of the pattern within that circle. Small rectangular portions of the dark and light areas are selected (depicted by dotted lines within the images in Tab 1). The same two areas are analyzed across all the images. The average pixel value $(\underline{x}=\Sigma x / n)$ is taken, and the difference $\left(\Delta=x_{d}-x_{l}\right)$ between these averages were calculated (where, $x_{d}$ and $x_{l}$ are defined as average dark pixel values and average light pixel values respectively). A reducing difference signifies an increase in turbidity. To prevent the possibility of floating particles from affecting the result the app also uses the OpenCV thresholding function to confirm turbidity, wherein if the pixel value is lower than the threshold value then it is assigned 0 (black) as per the OpenCV Reference Manual (2017). A threshold value of 90 was selected by a method of trial and error. The reducing count of non-black pixels after applying the thresholding function across the images indicates an increase in blurriness.

Table 1 Black pixel count after applying the threshold function on images at various stages of E. coli growth

\begin{tabular}{llll}
\hline Time & Description & Image taken & Image (Threshold applied) \\
\hline At start & $\begin{array}{l}\text { The backdrop of the test chamber is } \\
\text { clearly visible. }\end{array}$ & \\
\hline hours & Turbidity is noticed and presence of \\
later & coliforms can be confirmed.
\end{tabular}


After 6 The backdrop of the test chamber is hours
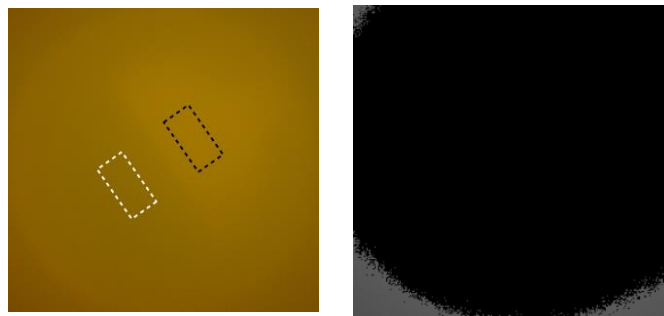

Table 1 shows that by applying the threshold function on the images we see the count of black pixels gradually increase signifying an increase in turbidity. Figure 4 shows graphical presentation of the point at which the app detects possible contamination and notifies the user about the same. Figure $4 \mathrm{a}$ is a line graph plotting the values determined by the two methods across the elapsed time and figure $4 \mathrm{~b}$ is the notification that the user would receive once the test has completed. This detection time and auto alert method is much faster when compared to the traditional manual system of visually determining the presence after 24 to 48 hours of incubation period. a.

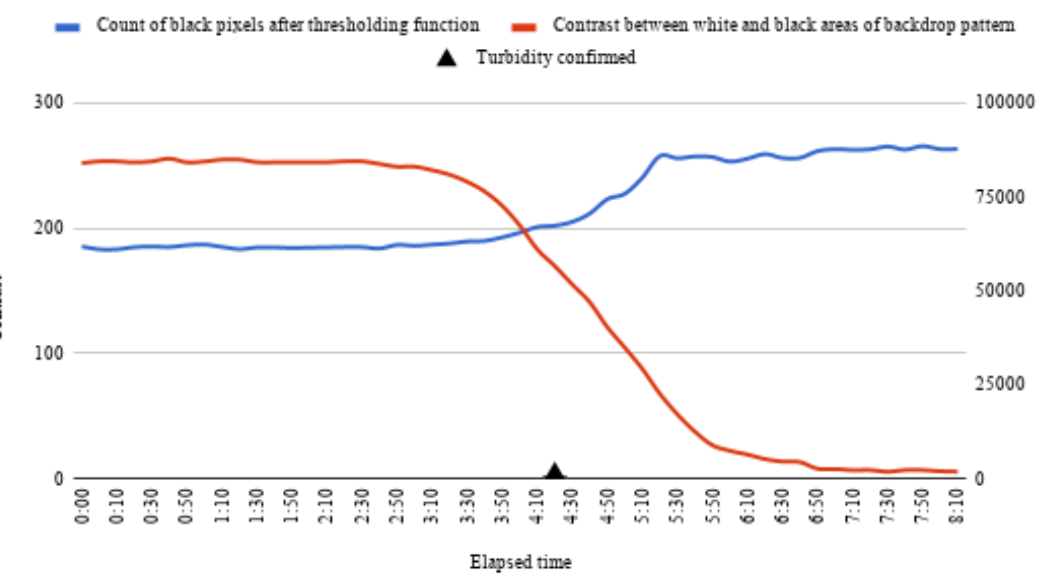

b.
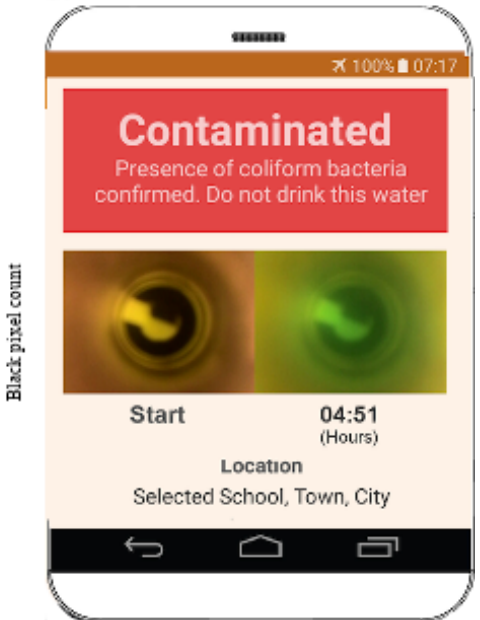

thods b) notification of result
As shown in figure 4 , the decision is made at the point where a sufficient change has been observed between white and black pixel values. The app continuously monitors the difference between the calculated values of initial image against the latest image. Once the app detects that the difference has crossed a preset threshold value the sample is considered to be contaminated and a notification is sent to the concerned parties.

\section{Response time of device with different concentrations of $E$. coli}

In order to determine the response time of coliform detection device for different concentration of coliform bacteria, the device was tested with water sample spiked with different concentrations of E. coli, i.e. $10^{0}-10^{1}, 10^{2}, 10^{3}, 10^{4}, 10^{5}, 10^{6}$,
$10^{7}, 10^{8}$, and $10^{9} \mathrm{CFU} / 100 \mathrm{ml}$, in triplicate for each concentration. The same tests were repeated for at least five times during the course of study. The water samples were simultaneously tested with a membrane filtration test (as a standard reference test). To confirm low level of coliform contamination i.e. in the range of 1-10 CFU/100 ml, a membrane filtration test was carried out by filtering 100 $\mathrm{ml}$ and $500 \mathrm{ml}$ of test water in replicates. A representative test data obtained with water samples having a concentration in the range of 1-10 CFU/100 ml is shown in figure 5. As seen in the figure 5a, the test water with 1-10 CFU/100 m analyzed by membrane filtration assay shows bacterial colonies after 24 hours of incubation. Since the tests were done in replicates, some plates have not shown any colony formation. Similar results were obtained by the coliform detection device for the same water samples.

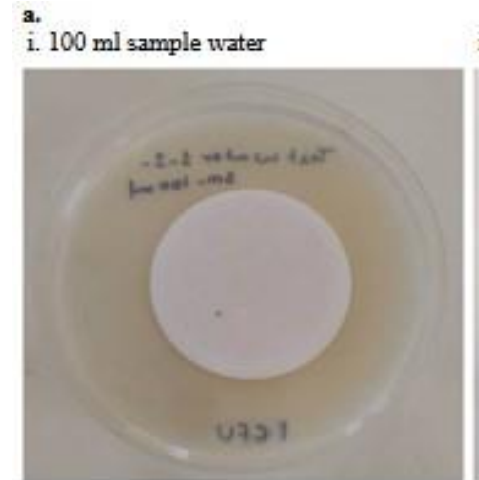

b. i. Contaminated

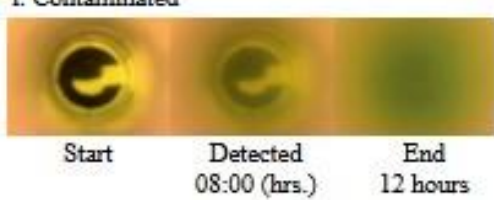

ii. $500 \mathrm{ml}$ sample water

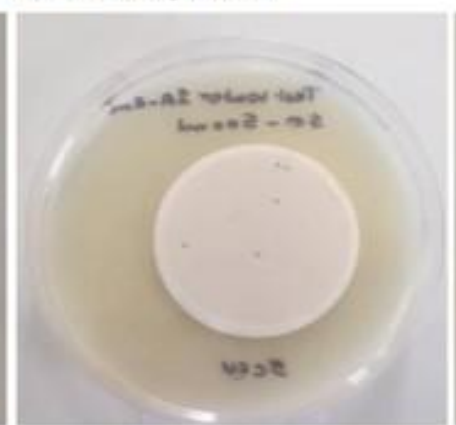

ii. Contaminated

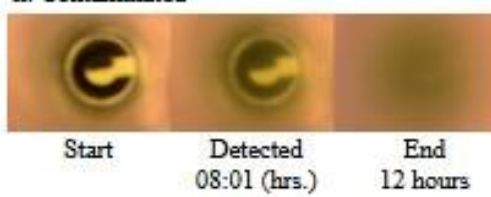

iii. $100 \mathrm{ml}$ sample water

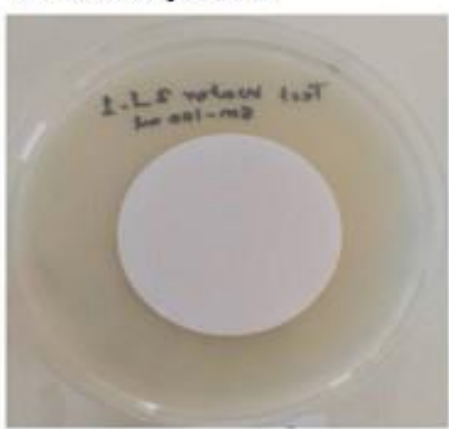

iii. Low Risk

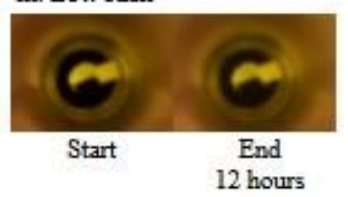

Figure 5 Analysis of test water contaminated with coliform at concentration of 1-10 CFU/100 ml test water by, a) membrane filtration assay (coliform is counted as the dark blue colonies on the membrane filter) b) images taken by the coliform detection device during the test 
Figure 6 illustrates the variation in the response time of the system for different concentrations of $E$. coli in the test water ranging from $10^{1}-10^{8} \mathrm{CFU} / 100 \mathrm{ml}$. As seen in figure 6 , it was found that the detection time reduces from 12 to 4 hours when $E$. coli concentration was increased from 1-10 CFU/100 $\mathrm{ml}$ to $10^{8} \mathrm{CFU} / 100$ $\mathrm{ml}$. The data also show a linear relationship between cell concentrations with respect to the time and thus the test could possibly also be used to interpret data semi-quantitatively or quantitatively with further optimization.

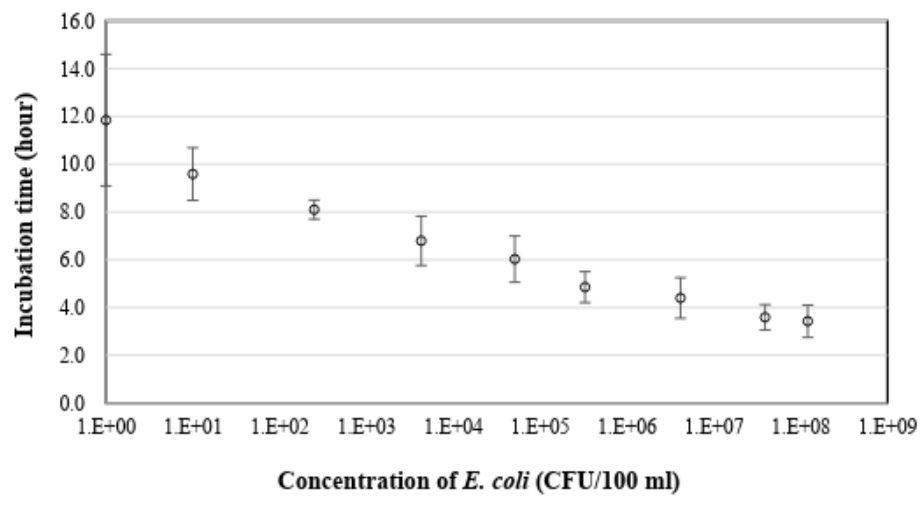

Figure 6 Time response of detection system with respect to E. coli concentration

\section{Data of water samples collected from different locations}

In addition to the artificially spiked $E$. coli samples, the system was used to test 35 water samples collected from different locations in Bangalore city, India. The water samples were mainly from roadside restaurants, households, municipal tap water, hand pumps and wells which people used for consumption. To confirm the actual concentration of $E$. coli, all the samples were also tested using a standard membrane filtration assay after appropriate dilution. All the controls were run as a reference test during observation. Figure 7 illustrates a representative test data obtained from control samples. As seen in the figure 7, test water spiked with Bacillus subtilis (Gram-positive bacteria) and Pseudomonas aeruginosa (Gramnegative bacteria) show no evidence of growth. Whereas, the test water spiked with Citrobacter freundii (Gram-negative coliform bacteria) and E. coli shows a positive test for coliform detection. Sterile test water and media control does not show any presence of bacterial growth.

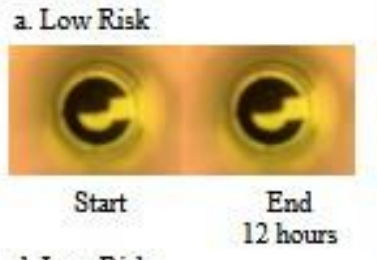

b. Low Risk

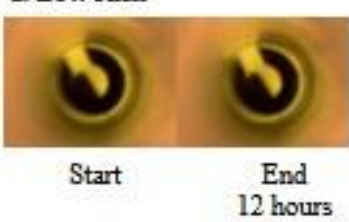

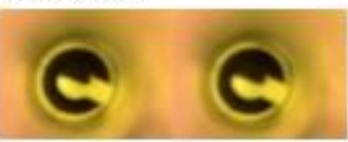

End Start e. Low Risk

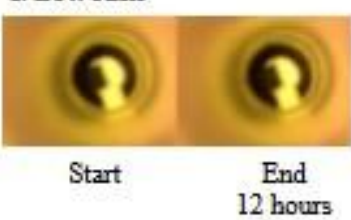

c. Contaminated

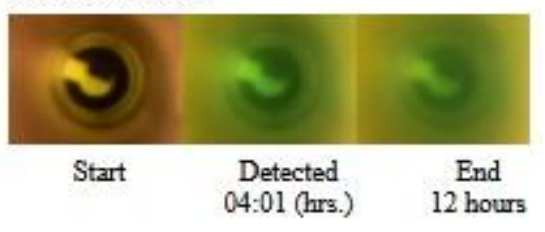

Figure 7 Data from control samples a) water sample spiked with Bacillus subtilis b) water sample spiked with Pseudomonas aeruginosa c) water sample spiked with Citrobacter freundii d) water sample with sterile tap water e) media control.

Table 2 depicts the data obtained by testing water samples collected from different locations in Bangalore city using coliform detection device and membrane filtration assay. As seen in Table 1, the time required for detecting presence/absence of coliform depends on the concentration of bacterial population present in the water samples. Thus, data on a high risk water sample can be communicated at an early stage.

Table 2 Testing presence coliform bacteria in water samples collected from different locations in Bangalore, India.

\begin{tabular}{|c|c|c|c|c|}
\hline \multirow[b]{2}{*}{$\begin{array}{l}\text { Sample } \\
\#\end{array}$} & \multirow[t]{2}{*}{ Locations } & \multicolumn{2}{|c|}{ Proposed device } & \multirow{2}{*}{$\begin{array}{c}\begin{array}{c}\text { Membrane } \\
\text { Filtration }\end{array} \\
\text { Number of } \\
\text { coliforms } \\
\text { per } 100 \mathrm{ml} \\
\text { sample }\end{array}$} \\
\hline & & $\begin{array}{c}\text { Presence/A } \\
\text { bsence } \\
\text { per } 100 \mathrm{ml} \\
\text { sample }\end{array}$ & $\begin{array}{c}\text { Detectio } \\
\text { n time in } \\
\text { hours } \\
\text { (Hours: } \\
\text { Minutes) }\end{array}$ & \\
\hline 1 & Household, Kalyan Nagar & Present & $08: 45$ & 13 \\
\hline 2 & Household, Kalyan Nagar & Present & $11: 30$ & 3 \\
\hline 3 & Restaurant, Kalyan Nagar & Present & $05: 30$ & $1.2 \times 10^{3}$ \\
\hline 4 & Office tap water, Kalyan Nagar & Present & $08: 40$ & 41 \\
\hline 5 & Roadside meal, Kalyan Nagar & Present & $03: 40$ & $2.52 \times 10^{5}$ \\
\hline 6 & Roadside stall, Kalyan Nagar & Present & 06:00 & $1.3 \times 10^{4}$ \\
\hline 7 & BDA complex, RT Nagar & Present & 12:00 & 2 \\
\hline 8 & Roadside meal, RT Nagar & Present & 06:00 & $1.46 \times 10^{3}$ \\
\hline 9 & Restaurant, RT Nagar & Present & 07:00 & 122 \\
\hline 10 & Restaurant, RT Nagar & Present & 04:30 & $4.9 \times 10^{3}$ \\
\hline 11 & Tap water, RT Nagar & Absent & $12: 00$ & 0 \\
\hline 12 & Juice shop, RT Nagar & Present & 03:50 & $5.5 \times 10^{4}$ \\
\hline
\end{tabular}

Present

\section{Tap water, Nandini Layout \\ Present}

Fast food stall, Nandini Layout

Borewell water, Nandini layout

Bakery, Nandini Layout

Bakery 2, Nandini Layout

Pool site, Uttarahalli

Borewell water, Uttarahalli

Construction site, Uttarahalli

Tap water, Uttarahalli

Sweet shop, Uttarahalli

Tea stall, Chowdaiah layout

Roadside meal, Chowdaiah layout

Household, Chowdaiah layout

Tea stall, Sultanpalya

Hotel, Rajaji Nagar

Hotel, Richmond Circle

Hotel, Langford Road

Tap water, Yelahanka

Tap water, Gokarna temple

Tap water, Kamalashile temple

Filtered water, Dharwad

Tap water, Bilekahalli

Tap water, Bilekahalli
Present

Present

Present

Present

Present

Present

Present

Present

Present

Present

Present

08:10 12

02:40 $7.2 \times 10^{6}$

$04: 10 \quad 6.2 \times 10^{5}$

07:40

87

$05: 30$

$4.9 \times 10^{3}$

11:50

3

07:50 68

06:00 $9.15 \times 10^{2}$

10:10

$$
8
$$

05:40 $1.2 \times 10^{3}$

08:30

56

$05: 10 \quad 2.4 \times 10^{3}$

Present

07:30

45

Present

05:30

$1.1 \times 10^{3}$

Present

09:50

6

Present

08:30

58

Present

05:00

$1 \times 10^{3}$

Present

05:50

$6.4 \times 10^{2}$

Present

09:30

12

Present

07:10

Present

04:50

$2.52 \times 10^{5}$

Present

03:10

$1.3 \times 10^{6}$ 
Most traditional methods of bacterial detection either in the laboratory or field are based on observing bacterial growth in specialized growth medium which favors selective growth of the target contaminants. In such methods the results are observed only at the completion of the test which could be after 24-48 hours of incubation. Generally, in a clear liquid growth medium the sign of bacterial growth starts appearing when the cell density reaches at a level of $10^{6}-10^{7}$ CFU/ml (Lewis et al., 2014).

Table 3 Comparisons of coliform detection test kits available in the market

\begin{tabular}{|c|c|c|c|c|c|c|c|}
\hline Product & Manufacturer/Website & Type of test & $\begin{array}{l}\text { Sample } \\
\text { volume } \\
(\mathrm{ml})\end{array}$ & $\begin{array}{l}\text { Detection } \\
\text { time } \\
\text { (Hours) }\end{array}$ & $\begin{array}{l}\text { Automatic } \\
\text { detection } \\
\text { /Early } \\
\text { warning } \\
\end{array}$ & $\begin{array}{l}\text { Accessories/ } \\
\text { Other } \\
\text { requirements }\end{array}$ & $\begin{array}{l}\text { Cost } \\
\text { per } \\
\text { test } \\
\text { (USD) } \\
\end{array}$ \\
\hline Proposed Device & - & P/A* & 100 & 4-8 & YES & Smartphone & 0.50 \\
\hline $3 \mathrm{M}$ Petrifilm ${ }^{\mathrm{TM}}$ & $\begin{array}{l}3 \mathrm{M} \\
\mathrm{www} .3 \mathrm{~m} . \mathrm{com}\end{array}$ & $\mathrm{CFU} / \mathrm{ml}(\mathrm{Q})^{* *}$ & 1 & 24 & $\mathrm{NO}$ & - & 1.59 \\
\hline Aquatest & $\begin{array}{l}\text { University of Bristol } \\
\text { www.bristol.ac.uk }\end{array}$ & $\mathrm{P} / \mathrm{A}$ & 100 & 24 & $\mathrm{NO}$ & - & 4.24 \\
\hline Bactaslyde & $\begin{array}{l}\text { Rakiro Biotech Systems Pvt. Ltd. } \\
\text { www.rakiro.net }\end{array}$ & $\mathrm{CFU}(\mathrm{SQ}) * * *$ & $\sim 1$ & $18-24$ & $\mathrm{NO}$ & - & 21.20 \\
\hline ChekNsee & $\begin{array}{l}\text { Rakiro Biotech Systems Pvt. Ltd. } \\
\text { www.rakiro.net }\end{array}$ & $\mathrm{P} / \mathrm{A}$ & 100 & $24-48$ & $\mathrm{NO}$ & - & 4.63 \\
\hline Colifast & $\begin{array}{l}\text { AquaFluor } \\
\text { www.turnerdesigns.com }\end{array}$ & $\mathrm{P} / \mathrm{A}$ & 10 & $2-11$ & $\mathrm{NO}$ & $\begin{array}{l}\text { Fluorescence } \\
\text { detector, incubator }\end{array}$ & 8.00 \\
\hline Colilert (P/A) & $\begin{array}{l}\text { IDEXX } \\
\text { www.idexx.com }\end{array}$ & $\mathrm{P} / \mathrm{A}$ & 100 & 24 & $\mathrm{NO}$ & Incubator & 5.97 \\
\hline Colilert 250 & $\begin{array}{l}\text { IDEXX } \\
\text { www.idexx.com }\end{array}$ & $\mathrm{P} / \mathrm{A}$ & 250 & 24 & $\mathrm{NO}$ & Incubator & 5.76 \\
\hline Colilert Quanti-Tray/2000 & $\begin{array}{l}\text { IDEXX } \\
\text { www.idexx.com }\end{array}$ & MPN (SQ) & 100 & $18-24$ & $\mathrm{NO}$ & Sealer, UV light & 6.94 \\
\hline Colilert ${ }^{\circledR} 18$ (P/A) & $\begin{array}{l}\text { IDEXX } \\
\text { www.idexx.com }\end{array}$ & $\mathrm{P} / \mathrm{A}$ & 100 & 18 & $\mathrm{NO}$ & Incubator & 5.76 \\
\hline Coliplate & $\begin{array}{l}\text { Bluewater Bioscience Inc. } \\
\text { bluewaterbiosciences.com }\end{array}$ & SQ & 100 & 24 & $\mathrm{NO}$ & Incubator, UV light & 10.88 \\
\hline Coliscan CWK10 & $\begin{array}{l}\text { Micrology Laboratories } \\
\text { www.micrologylabs.com }\end{array}$ & $\mathrm{P} / \mathrm{A}$ & 5 & $36-48$ & $\mathrm{NO}$ & - & 3.28 \\
\hline Coliscan ${ }^{\circledR}$ MF & $\begin{array}{l}\text { Micrology Laboratories } \\
\text { www.micrologylabs.com }\end{array}$ & CFU/100 ml (Q) & 100 & $18-24$ & $\mathrm{NO}$ & - & 4.75 \\
\hline Colisure $\mathbb{R}(\mathrm{P} / \mathrm{A})$ & $\begin{array}{l}\text { IDEXX } \\
\text { www.idexx.com }\end{array}$ & $\mathrm{P} / \mathrm{A}$ & 100 & 24 & $\mathrm{NO}$ & Incubator & 5.76 \\
\hline $\begin{array}{l}\text { Compartmentalized bag test } \\
\text { (CBT) }\end{array}$ & $\begin{array}{l}\text { Aquagenx } \\
\text { www.aquagenx.com }\end{array}$ & MPN (SQ) & 100 & 24 & $\mathrm{NO}$ & - & 7.39 \\
\hline $\mathrm{E} *$ Colite & $\begin{array}{l}\text { Charm Sciences, Inc. } \\
\text { www.charm.com }\end{array}$ & P/A & 100 & $24-48$ & $\mathrm{NO}$ & - & 9.64 \\
\hline EC Blue100P & $\begin{array}{l}\text { Nissui Pharmaceutical Co. Ltd. } \\
\text { www.medica-tec.com }\end{array}$ & $\mathrm{P} / \mathrm{A}$ & 100 & 24 & $\mathrm{NO}$ & UV source & 6.12 \\
\hline EC BlueQuant & $\begin{array}{l}\text { Carl Roth GmbH + Co. KG } \\
\text { www.carlroth.com }\end{array}$ & MPN (SQ) & 100 & 24 & $\mathrm{NO}$ & Incubator, UV light & 19.04 \\
\hline Hach Bacteria Bottle & $\begin{array}{l}\text { Hach } \\
\text { www.hach.com }\end{array}$ & $\mathrm{P} / \mathrm{A}$ & 100 & 24 & $\mathrm{NO}$ & - & 4.21 \\
\hline HiWater Test Kit & $\begin{array}{l}\text { Hi Media } \\
\text { www.himedialabs.com }\end{array}$ & $\mathrm{P} / \mathrm{A}$ & 100 & 24 & $\mathrm{NO}$ & - & 8.33 \\
\hline $\begin{array}{l}\text { Lamotte }{ } \text { Total Coliform Test } \\
\text { Kit }\end{array}$ & $\begin{array}{l}\text { LaMotte } \\
\text { www.lamotte.com }\end{array}$ & MPN (SQ) & 100 & $40-48$ & $\mathrm{NO}$ & UV light & 15.80 \\
\hline $\begin{array}{l}\text { Microtester Pro E.coli water } \\
\text { testing Kit }\end{array}$ & $\begin{array}{l}\text { Simpltek } \\
\text { www.simpltek.com }\end{array}$ & $\mathrm{CFU} / \mathrm{ml}(\mathrm{Q})$ & 10 & $2-15$ & $\mathrm{NO}$ & UV light & 7.71 \\
\hline Modified ColitagTM & $\begin{array}{l}\text { CPI International } \\
\text { www.cpiinternational.com }\end{array}$ & MPN (SQ) & 100 & $16-48$ & $\mathrm{NO}$ & $\begin{array}{l}\text { Incubator, } \\
\text { lamp }\end{array}$ & 6.06 \\
\hline mWater test kit & $\begin{array}{l}\text { mWater } \\
\text { www.mwater.com }\end{array}$ & $\mathrm{CFU} / \mathrm{ml}(\mathrm{Q})$ & 1 & 24 & Yes & - & 8.94 \\
\hline Rapid Hicoliform Test Kit & $\begin{array}{l}\text { Hi Media } \\
\text { www.himedialabs.com }\end{array}$ & $\mathrm{P} / \mathrm{A}$ & 100 & 24 & $\mathrm{NO}$ & Incubator, UV light & 3.47 \\
\hline Readycult $\mathbb{R}$ & $\begin{array}{l}\text { EM Science EMD Chemicals } \\
\text { www.vgdusa.com }\end{array}$ & $\mathrm{P} / \mathrm{A}$ & 100 & 24 & $\mathrm{NO}$ & - & 5.42 \\
\hline $\begin{array}{l}\text { Water Pollution: Coliform } \\
\text { Presumptive Test Kit }\end{array}$ & $\begin{array}{l}\text { Carolina Biological } \\
\text { www.carolina.com }\end{array}$ & $\mathrm{P} / \mathrm{A}$ & 10 & $24-48$ & $\mathrm{NO}$ & Incubator & 4.96 \\
\hline Water Works Bacteria test kit & $\begin{array}{l}\text { Filterwater } \\
\text { www.filterwater.com }\end{array}$ & $\mathrm{P} / \mathrm{A}$ & 100 & 24 & $\mathrm{NO}$ & - & 10.55 \\
\hline Watercheck ${ }^{\mathrm{TM}}[\mathrm{BWB}]$ & $\begin{array}{l}\text { Bluewater Bioscience Inc. } \\
\text { www.bluewaterbiosciences.com }\end{array}$ & $\mathrm{P} / \mathrm{A}$ & 100 & $48-72$ & $\mathrm{NO}$ & - & 8.21 \\
\hline $\begin{array}{l}\text { WaterWorks }{ }^{\mathrm{TM}} \text { EZ Coliform } \\
\text { Cult Bacteria }\end{array}$ & $\begin{array}{l}\text { Industrial Test Systems Inc. } \\
\text { www.itseurope.co.uk }\end{array}$ & $\mathrm{P} / \mathrm{A}$ & 100 & $24-48$ & $\mathrm{NO}$ & - & 8.68 \\
\hline WaterWorks ${ }^{\mathrm{TM}}$ & $\begin{array}{l}\text { Industrial Test Systems Inc. } \\
\text { www.itseurope.co.uk }\end{array}$ & $\mathrm{P} / \mathrm{A}$ & 100 & $24-48$ & $\mathrm{NO}$ & - & 5.21 \\
\hline Zayho & Zayho/www.zayho.com & $\mathrm{P} / \mathrm{A}$ & 10 & $24-48$ & $\mathrm{NO}$ & - & 13.73 \\
\hline
\end{tabular}

*P/A, Presence/Absence; **SQ, Semiquantitative; ***Q, Quantitative

Disclaimer: The information in this price list is presented in good faith and believed to be correct at the time of this article. The prices were obtained from the vendors' websites and we make no representations or warranties as to the completeness or accuracy of the information.

Considering the bacterial generation time, the time required to achieve this threshold depends on the initial number of bacterial cells (Powell, 1956; Wang et al., 2015). Thus, higher levels of contamination can be detected at a much earlier stage. Although the system described in this work measures growth of coliform like any other conventional method, continuous monitoring of bacterial growth and receiving of an early alert as soon as a visible sign of contamination is 
detected is an innovative features in the work. In addition, the changes in color of the media are captured by the camera, which happens as a result of breakdown of chromogenic and fluorogenic substrate, X-Gal (5-bromo-4-chloro-3-indolyl- $\beta$-D galactoside) and (4-methylumbelliferyl-beta-D-glucuronide) respectively due to the presence of enzyme $\beta$-D-galactosidase and $\beta$-D-glucuronidase in a coliform group of bacteria. This also signifies confirmation of target bacteria. The laboratory prototype of coliform detection device (figure 2) has been repeatedly tested at least five times with different concentrations of coliform to determine the sensitivity of the test. The results obtained showed that to detect 1-10 CFU/100 $\mathrm{ml}$ it requires approximately 8-12 hours. It was found that for samples having a concentration in the range of $10^{3}-10^{6} \mathrm{CFU} / 100 \mathrm{ml}$, the results can be interpreted within 4-6 hours time (figure 5). In addition, the user gets an alert as soon as the system detects the presence of coliform, which reduces the time required for observing and interpreting data visually. This was further confirmed by analyzing water samples collected from different locations. The membrane filtration technique, used for confirming the results, estimates coliform contamination only after 24 hours irrespective of the level of contamination in water samples, whereas, the testing done with the proposed device was able to detect contamination within 4-12 hours. Further, the results may also be extracted, transferred to a database and used for mapping high risk area with respect to waterborne diseases. The detection system developed in the work if implemented, would be simple to use and can be easily carried to almost any site, thus benefiting regions that lack access to water testing facilities and thus has potential to use in the field. The costs involved are minimal and the test chamber and incubator that is used can be produced in small facility with minima investment. The consumables are also easily available or can be prepared as a batch and stored. The selective media used in the system is commercially available. Old unused smartphone can be utilized to further reduce the initial cos of the system. Table 3 provides a comparison of the coliform detection method developed in the current work against most commonly available coliform detection kits in the market. Costs mentioned in the table are per test without considering the upfront costs of equipment and accessories and based on consumable required per test.

As seen in the Table 3, all the tests are based on three main approaches to detect coliform contamination i.e. Presence/Absence based on detection of growth or color change, quantitative enumeration as colony forming unit using membrane filtration or plating and a semi quantitative most probable number (MPN) test where a dilution and a statistical method is used to estimate the level of contamination. Also evident is that the estimated cost of current test device is comparable to the other test kits.

In the current study, on-site analysis using the device was not carried out and would be scheduled for later stages. One of the challenges we may face during on-site analysis could be dealing with high levels of turbidity at some sources due to the presence of suspended particulates. This issue can be tackled by passing the water sample through a pre-filter before passing it through the membrane unit. In conclusion, for resource poor settings or regions that does not have access to water testing laboratories, or technical expertise, the smartphone-based detection system developed in the work holds promise.

Future scope of the present study involves, extensive study on performance of device in presence of mixed bacterial strains, analysis of different smartphone models and its effect on the quality of pictures taken by its built-in camera enhancing the sensitivity of the detection system to further reduce the time frame, externalizing the camera so that multiple tests can be carried out using a single smartphone and investigating the possibility of optimizing the image processing software for quantitative test. Application of the above test system for detection of other pathogenic microorganisms present in water and food is also one of the focus areas of our present work.

\section{CONCLUSION}

We have proposed a proof of concept for a low-cost device that can be attached to a smartphone, custom designed test chamber and image processing software to detect the presence of coliform $/ E$. coli contamination. The smartphone camera and image processing software are designed to monitor active multiplication of bacteria in a selective growth medium and programmed to send an alert as soon as the sign of growth is evident within a time period of 4 to 12 hours. The test is suitable for on-site field application and can be performed without the requirement of expensive laboratory facilities. The software application integrated with the test was also designed to eliminate the scope of user errors in interpretation of the test result

Acknowledgments: The authors would like to thank the Akvo Foundation, Amsterdam, Netherlands, for supporting this research. We would also like to thank Dr. Suchitra Joyce for technical support. Also thanks to Thomas Bjelkeman-Pettersson, Mark Tiele Westra and Hans Merton of The Akvo Foundation, Netherlands, for comments and support.

\section{REFERENCES}

APHA (AMERICAN PUBLIC HEALTH ASSOCIATION), 2012. Standard methods of water and wastewater. $22^{\text {th }}$ ed. American Public Health Association, American Water Works Association, Water Environment Federation publication, Washington D.C.

ASHBOLT, N. J. 2015. Microbial contamination of drinking water and human health from community water systems. Curr Environ Health Rep, 2(1), 95106.https://doi.org/10.1007/s40572-014-0037-5

ATLAS, R. M., BEJ, A. K. 1990. Detecting bacterial pathogens in environmenta water samples by using PCR and gene probes. PCR Protocols, 399406.https://doi.org/10.1016/b978-0-12-372180-8.50052-4

BAIN, R. B., ELLIOTT, M., MATTHEWS, R., MCMAHAN, L., TUNG, R., CHUANG, P., GUNDRY, S. 2012. A summary catalogue of microbial drinking water tests for low and medium resource settings. Int $J$ Environ Res Public Health, 9(5), 1609-1625. https://doi.org/10.3390/ijerph9051609

BELLIN, T., PULZ, M., MATUSSEK, A., HEMPEN, H. G., GUNZER, F. 2001 Rapid detection of enterohemorrhagic Escherichia coli by real-time PCR with fluorescent hybridization probes. $J$ Clin Microbio, 39, 370374.https://doi.org/10.1128/icm.39.1.370-374.2001

CENTERS FOR DISEASE CONTROL AND PREVENTION (CDC). 2010 Microbiological indicator testing in developing countries: a fact sheet for the field practitioner. Atlanta, Georgia, United States.https://sanitationupdates.files.wordpress.com/2010/11/microbiology2020.p $\underline{\text { df }}$

DEL'DUCA, A., CESAR, D.E., ABREU, P.C. 2015. Bacterial community of pond's water, sediment and in the guts of tilapia ( $\mathrm{O}$ reochromis niloticus) juveniles characterized by fluorescent in situ hybridization technique. Aquacult Res, 46(3), 707 715.https://doi.org/10.1111/are.12218

ESFANDIARI, P., AMANI, J., FOULADI, A.A.I., NAZARIAN, S., MIRHOSSEINI, A., MOGHIMI, E. 2017. Rapid and specific polymerase chain reaction-enzyme linked immunosorbent assay for detection of Escherichia coli LT toxin from clinical isolates. Arch Clin Infect Dis, 12(1).https://doi.org/10.5812/archcid.36261

EZENARRO, J. J., URIA, N., CASTILLO-FERNÁNDEZ, Ó., PÁRRAGA, N. SABRIÀ, M., PASCUAL, F. X. M. 2018. Development of an integrated method of concentration and immunodetection of bacteria. Anal Bioanal Chem, 410(1), 105-113.https://doi.org/10.1007/s00216-017-0695-x

FALCO R, WILLIAMS S. I. 2009. Waterborne Salmonella outbreak in Alamosa Colorado March and April 2008. Outbreak identification response and investigation. Safe Drinking Water Program, Water Quality Control Division, Colorado Department of Public Health and Environment https://www.marlerblog.com/uploads/file/AlamosaInvestRpt.pdf

FATEMEH, D., REZA, Z. M., MOHAMMAD, A., SALOMEH, K., REZA, A G., HOSSEIN, S., MARYAM, S., AZAM A., MANA S. NEGIN, N., REZA, K.A., SAEED, F. 2014. Rapid detection of coliforms in drinking water of Arak city using multiplex PCR method in comparison with the standard method of culture (Most Probably Number). Asian Pac J Trop Biomed, 4(5), 404 - 409. https://doi.org/10.12980/apjtb.4.2014c896

GIRONES, R., FERRÚS, M. A., ALONSO, J. L., RODRIGUEZ-MANZANO, J., CALGUA, B., DE ABREU CORRÊA ADE, A, HUNDESA, A. CARRATALA, A., BOFILL-MAS, S. 2010. Molecular detection of pathogens in water-the pros and cons of molecular techniques. Water Res, 44(15), 43254339.https://doi.org/10.1016/j.watres.2010.06.030

GUNDA, N.S.K., NAICKER, S., SHINDE, S., KIMBAHUNE, S. SHRIVASTAVA, S., MITRA, S. 2014. Mobile Water Kit (MWK): a smartphone compatible low-cost water monitoring system for rapid detection of total coliform and E. coli. Anal Methods, 6(16), 6236-6246. https://doi.org/10.1039/c4ay01245c GUNDA, N.S.K., CHAVALI, R., MITRA, S. K. 2016. A hydrogel based rapid test method for detection of Escherichia coli (E. coli) in contaminated water samples. Analyst, 141(10), 2920-2929.https://doi.org/10.1039/c6an00400h

HAAS, A.J., GIBBONS, D., DANGEL, C., ALLGEIER, S. 2011. Automated surveillance of 911 call data for detection of possible water contamination incidents. Int J Health Geogr, 10(1), 22. https://doi.org/10.1186/1476-072x-10 22

HASAN, J., STATES, S., DEININGER, R. 2009. Safeguarding the security of public water supplies using early warning systems: a brief review. J Contemp Water Res Educ., 129 (1), 27-33.https://doi.org/10.1111/j.1936704x.2004.mp129001007.x

HEIJNEN, L., MEDEMA G. 2009. Method for rapid detection of viable Escherichia coli in water using real-time NASBA. Water Res, 43, 3124 3132.https://doi.org/10.1016/j.watres.2009.04.025

HOLME, R. 2003. Drinking water contamination in Walkerton, Ontario: positive resolutions from a tragic event. Wat Sci Tech, 47(3), 1-6. https://doi.org/10.2166/wst.2003.0144

HORAKOVA, K., MLEJNKOVA, H., MLEJNEK, P. 1991. Specific detection of Escherichia coli isolated from water samples using polymerase chain reaction targeting four genes: cytochrome bd complex, lactose permease, $\beta$ - $d$ glucuronidase, and $\beta$-d-galactosidase. J Appl Microbiol, 105(4), 970-976 https://doi.org/10.1111/j.1365-2672.2008.03838.x 
HRUDEY, S.E., HRUDEY, E.J., POLLARD, S.J. 2006. Risk management for assuring safe drinking water. Environ Int, 32(8), 948-957. https://doi.org/10.1016/j.envint.2006.06.004

KONG, R. Y. C., LEE, S.K.Y., LAW, T.W.F., LAW, S.H.W., WU, R.S.S. 2002 Rapid detection of six types of bacterial pathogens in marine waters by multiplex PCR. Water Res, $\quad 36(11), \quad$ 2802-2812.https://doi.org/10.1016/s00431354(01)00503-6

LEVIN, S., KRISHNAN, S., RAJKUMAR, S., HALERY, N., BALKUNDE, P 2016. Monitoring of fluoride in water samples using a smartphone. Sci Total Environ, 551, 101-107.https://doi.org/10.1016/j.scitotenv.2016.01.156

LEWIS, C. L., CRAIG, C. C., SENECAL, A.G. 2014. Mass and density measurements of live and dead gram-negative and gram-positive bacterial populations. Appl Environ Microbiol, $80 \quad$ (12), 3622-3631. https://doi.org/10.1128/aem.00117-14

LIANG, P. S., PARK, T. S., YOON, J. Y. 2014. Rapid and reagentless detection of microbial contamination within meat utilizing a smartphone-based biosensor Sci Rep, 4(1), 5953.https://doi.org/10.1038/srep05953

LOPEZ-RUIZ, N., CURTO, V. F., ERENAS, M.M., BENITO-LOPEZ, F., DIAMOND, D., PALMA, A. J., CAPITAN-VALLVEY, L. F. 2014 Smartphone-based simultaneous $\mathrm{pH}$ and nitrite colorimetric determination for paper microfluidic systems. Anal Chem, 86(19), 9554 9562.https://doi.org/10.1021/ac5019205

MARTIN, N. H., TRMČIĆ, A., HSIEH, T. H., BOOR, K. J., WIEDMANN, M. 2016. The evolving role of coliforms as indicators of unhygienic processing conditions in dairy foods Front Microbiol, 7, 18.https://doi.org/10.3389/fmicb.2016.01549

MCDANIELS, A. E., BORDNER, R. H. 1983. Effects of holding time and temperature on conform numbers in drinking water. J Am Water Works Assoc, 75(9), 458-463.https://doi.org/10.1002/j.1551-8833.1983.tb05195.x

MCMAHON, T. C., BLAIS, B. W., WONG, A., CARRILLO, C.D. 2017. Multiplexed single intact cell droplet digital PCR (MuSIC ddPCR) method for specific detection of enterohemorrhagic E. coli (EHEC) in food enrichment cultures. Front Microbiol, 8,332. https://doi.org/10.3389/fmicb.2017.00332

MENDES SILVA, D.M., DOMINGUES, L. 2015. On the track for an efficient detection of Escherichia coli in water: A review on PCR-based methods. $\begin{array}{llll}\text { Ecotoxicol Environ } & \text { Saf, } & 113, & 400-\end{array}$ 411.https://doi.org/10.1016/j.ecoenv.2014.12.015

NYGÅRD, K., SCHIMMER, B., SØBSTAD, Ø., WALDE, A., TVEIT, I, LANGELAND, N., AAVITSLAND, P. 2006. A large community outbreak of waterborne giardiasis-delayed detection in a non-endemic urban area. $B M C$ Public Health 6(1), 141. https://doi.org/10.1186/1471-2458-6-141

ODONKOR, S. T., AMPOFO, J. K. 2013. Escherichia coli as an indicator of bacteriological quality of water: an overview. Microbiol Res, 4(1).https://doi.org/10.4081/mr.2013.e2

OLIVEIRA, M., SERRANO, I., VAN HARTEN, S., BESSA, L. J., BERNARDO, F., DA COSTA, P. M. 2016. Fecal contamination of wastewater treatment plants in Portugal. Environ Sci Pollut $R$, 23(14), 1467114675.https://doi.org/10.1007/s11356-016-6962-0

OPENCV. The OpenCV Reference Manual, http://opencv.org [Accesses on: $10^{\text {th }}$ March, 2019].

POWELL, E.O. 1956. Growth rate and generation time of bacteria, with special reference to continuous culture. J Gen Microbiol, 15(3), 492511.https://doi.org/10.1099/00221287-15-3-492

PRICE, R.G., WILDEBOER, D. 2017. E. coli as an Indicator of Contamination and Health Risk in Environmental Waters. Escherichia coli- Recent Advances on Physiology, Pathogenesis and Biotechnological Applications.https://doi.org/10.5772/67330

RANGETI, I., DZWAIRO B., BARRATT G.J., OTIENO F. 2015. Validity and Errors in Water Quality Data - A Review. In: Teang (Ed.), Research and Practices in Water Quality.https://doi.org/10.5772/59059

RATENI, G., DARIO, P., CAVALLO, F. 2017. Smartphone-based food diagnostic technologies: a review. Sensors, 17(6), 1453 https://doi.org/10.3390/s17061453

RIZAK, S., HRUDEY, S.E. 2006. Misinterpretation of drinking water quality monitoring data with implications for risk management. Environ Sci Technol, (17), 5244-5250.https://doi.org/10.1021/es0520417

RIZAK, S., HRUDEY, S. E. 2007. Response to Comment on "Misinterpretation of Drinking Water Quality Monitoring Data with Implications for Risk $\begin{array}{llll}\text { Management. Environ Sci Technol, 41(9), } 3389 & \end{array}$

3390.https://doi.org/10.1021/es070462d

ROMPRÉ, A., SERVAIS, P., BAUDART, J., DE-ROUBIN, M.R., LAURENT, P. 2002. Detection and enumeration of coliforms in drinking water: current methods and emerging approaches. J. Microbiol Methods, 49 (1), 3154.https://doi.org/10.1016/s0167-7012(01)00351-7

PARK, T. S., YOON, J. Y. 2015. Smartphone detection of Escherichia coli from field water samples on paper microfluidics. IEEE Sens. J, 15(3), 19021907.https://doi.org/10.1109/jsen.2014.2367039

SICARD, C., GLEN, C., AUBIE, B., WALLACE, D., JAHANSHAHIANBUHI, S., PENNINGS, K., DAIGGER, G.T., PELTON, BRENNAN, J. D., FILIPE, C. D. 2015. Tools for water quality monitoring and mapping using paper-based sensors and cell phones. Water Res, 70, 360369.https://doi.org/10.1016/j.watres.2014.12.005

TAKAHASHI, H., SAITO, R., MIYA, S., TANAKA, Y., MIYAMURA, N. KUDA, T., KIMURA, B. 2017. Development of quantitative real-time PCR for detection and enumeration of Enterobacteriaceae. Int J Food Microbiol, 246, 92 97. https://doi.org/10.1016/j.ijfoodmicro.2016.12.015

UNEP/WHO, 1996. Water Quality Monitoring - A Practical Guide to the Design and Implementation of Freshwater Quality Studies and Monitoring Programmes. United Nations Environment Programme and the World Health, Organization. http://www. who.int/water sanitation health/resourcesquality/wqmohap.

WALKER, D.I., MCQUILLAN, J., TAIWO, M., PARKS, R., STENTON, C.A. MORGAN, H., MOWLEM, M.C., LEES, D.N. 2017. A highly specific Escherichia coli qPCR and its comparison with existing methods for environmental waters. Water Res, 126, 101-110 https://doi.org/10.1016/j.watres.2017.08.032

WANG, L., FAN, D., CHEN, W., TERENTJEV, E. M. 2015. Bacterial growth, detachment and cell size control on polyethylene terephthalate surfaces. Scientific Reports, 5(1).https://doi.org/10.1038/srep15159

YETISEN, A. K., MARTINEZ-HURTADO, J. L., GARCIA-MELENDREZ, A., DA CRUZ VASCONCELLOS, F., LOWE, C.R. 2014. A smartphone algorithm with inter-phone repeatability for the analysis of colorimetric tests. Sens Actuators B Chem, 196, 156-160. https://doi.org/10.1016/j.snb.2014.01.077

ZULKIFLI, S.N., RAHIM, H.A., LAU, W.J. 2018. Detection of contaminants in water supply: A review on state-of-the-art monitoring technologies and their applications. Sens Actuators $B \quad$ Chem, 255, 2657-2689. https://doi.org/10.1016/j.snb.2017.09.078 